\title{
Experiencing Migration: A Child in a New Socio-Cultural Environment
}

\begin{abstract}
The paper is devoted to chosen aspects of the situation of a child with migration experience in a new socio-cultural reality. The analyses undertaken in the article show the dilemmas and difficulties which accompany an individual functioning in the conditions of cultural differences. The text consists of two complementary parts. The first one presents specificity of enculturation and acculturation processes (learning of own and new culture). The second part describes the threads related to experiencing cultural differences and their psychological and social consequences. The consideration included in the paper enrich the narratives of people who experienced/are experiencing migration (mainly in the childhood) which are the results of empirical research (Polish context). The article may be useful to everyone who is interested in the issues of socio-cultural adaptation of children with migration experience.
\end{abstract}

Keywords:

experience of migration, child, acculturation, cultural differences, education

\section{INTRODUCTION}

In the modern world of dynamic changes and conflicts, the childhood of millions of children is shaped in a situation of migration - at the crossroads of cultures, in conditions of socio-cultural and civilizational differences. Each migration takes place in a dynamic weave of family, social, economic and political conditions. Each migrant has a specific personality and psychological distinctiveness. The

1 Faculty of Education, University of Białystok, Poland.

E-MAIL: a.mlynarczuk-sokolowska@uwb.edu.pl ORCID: 0000-0002-3355-0098 
interpenetration of two groups of factors, which are, on the one hand, external circumstances accompanying migration, and on the other hand - internal personality conditions, largely determines the course and success of migration (Kubitsky, 2012, p. 85). Changing the place of residence in a more or less rapid way forces the necessity to contact and move within a different culture and social reality. Thus, it triggers the process of acquiring new life experiences and learning. These experiences are irrevocably inscribed in human biographies and are factors shaping their life paths.

The aim of the article is to analyze selected aspects of the situation of a child with migration experience in the new socio-cultural reality. ${ }^{2}$ The text begins with presenting the specificity of learning processes of one's own and a new culture (enculturation and acculturation). Then it focuses on the themes of experiencing cultural differences (biographical perspective) and their psychological and social consequences. The analyses included in the paper enrich the narratives of people who experienced/are experiencing migration (mainly in the childhood) which are the results of empirical research (Polish context). ${ }^{3}$

\section{AN INDIVIDUAL IN THE PROCESS OF LEARNING THE CULTURE OF OWN GROUP AND GETTING TO KNOW THE CULTURE OF A NEW COUNTRY}

According to Jerzy Nikitorowicz (2005a, 2009), culture is a social, normative, historical, symbolic and psychological phenomenon. Cultural influences and conditions can be found in every aspect of human life: the iconosphere of everyday life, architecture, fine arts, music, style of clothing, etc. Culture shapes both what is visible, i.e., patterns of behavior, habits, and also what is invisible, i.e., values, norms and worldview. People process already existing cultural content and give it

2 The article analyzes selected processes related to migration, taking into account its various types (e.g., economic, or forced, i.e., refugeeism).

3 Those are the following studies carried out by the author of the text: "Przestrzeń szkoły w percepcji uczniów z doświadczeniem migracji uchodźczej” [Space of School in the Perception of Students with Refugee Background] (2019) (research carried out among students of Białystok primary schools [at the age of 10-16 years old] using the method of visual ethnography [participant photography] and narrative interview); “Doświadczenia Polaków związane z akulturacją w wybranych krajach europejskich oraz migracją powrotną” [Poles’ Experiences Related to Acculturation in Selected European Countries and Return Migration] (2017) (five unstructured interviews conducted among adults living in the Podlasie province); “Doświadczenia cudzoziemców dotyczące akulturacji w Polsce” [Experiences of Foreigners Regarding the Acculturation Process in Poland] (2017) (ten unstructured interviews conducted among foreigners at different ages, starting from adolescence [13 years old] to adulthood, living in the Podlasie province). 
a meaning (Nikitorowicz, 2005a, 2009). From a psychological perspective, culture can be defined as a set of elements that make up many aspects of a person's cognitive, emotional, and behavioral functioning, ranging from perception through communication to behavior. This is well reflected in Geert Hofstede's view, according to which culture is a collective mind software that distinguishes members of one social group from another (Hofstede, Hofstede, \& Minkov, 2010).

Culture is always someone's culture. It is specific people who are its creators, they express themselves through it and communicate within it. At the same time, culture is not something that is unknowingly absorbed (Dyczewski, 1996, p. 11). A person learns to move and express in one's own culture from an early age (both unconsciously and consciously). In this way, the individual successively 'grows' into the culture of the society, becoming its integral member and 'carrier'. This process is called enculturation. As a result, a person learns the individual elements of the culture of the group and at the same time acquires the so-called cultural competence, understood as the entirety of abilities that define the cultural behavior of a person (Bednarski, 1987, pp. 75-77). Culture contributes to the consolidation, dissemination and strengthening of similarities and behavioral differences, generating a kind of feedback cycle between actual behavior and social knowledge about the behaviors that socially and culturally define a person (Matsumato \& Juang, 2007, p. 23).

In the course of the enculturation process, an individual learns not only how to behave, but also how to understand (interpret) the behavior of others. It is connected with experiencing strong emotional reactions (which result from the fact that a person becomes involved in the acceptance-rejection continuum) related to the formulation of moral judgments to which the behavior of another person is subjected, but also to which the person is subjected (in terms of good-bad, right-wrong). It is also a necessity to assess the personality of another people, but - what is important - in the society everyone evaluates the personality of another person and at the same time everyone is the subject of such assessment (JurgielAleksander, 2013, pp. 46-47).

Human being notices the existence of different cultures under the conditions of cultural difference. When an individual notices a different way of dressing, speaking, thinking, comprehending time or preferred cuisine, he or she begins to realize that there are diverse cultures (Nikitorowicz, 2005a, p. 120). According to the Iceberg Model of Culture created by Edward T. Hall (1976), cultural difference is usually noticed gradually. Firstly, a person experiences its visible elements (a different way of dressing, behaving, cooking, etc.). Migration is characterized by the fact that, without a reason for leaving, they always uproot themselves from 
the model of the world, culture and language, and thus force them to act in an unknown world, to find themselves in the culture and language of the host country (Kożyczkowska \& Młynarczuk-Sokołowska, 2018). Changing the country of residence and every stay abroad shows, among others, that the national character of individual cultures is not an abstraction (Kubitsky, 2012). With time, it begins to manifest itself in every aspect of life: in the way of reasoning, in the hierarchy of values and social institutions, their structure and mode of functioning. The change of the place of residence, the natural consequence of which is the contact of cultures, and the specifically forced movement within the new culture may be accompanied by a number of both positive and negative emotions of varying intensity (Nikitorowicz, 2005b, p. 120). Analyzing enculturation from a biographical perspective, one can recognize in this process the human being as a learning entity. This means that a person learns and gains knowledge from experience as well as through experience. In the case of human entanglement in the reality of cultural difference, it is necessary to treat the multicultural situation, and the experience resulting from it, as a specific potential or even a structure that is socially and culturally produced (Jurgiel-Aleksander, 2013, p. 47).

At the beginning of a stay in a new country, various reality and human behavior may attract the attention of adults and children and thus, arouse interest and excitement (Barzykowski et al., 2013, p. 75). Cultural differences determine the behavior of members of the new society, their style of verbal and non-verbal communication. Everything is visible in the public space and may seem interesting, surprising, worth following, and even shocking in a positive way. The affective and cognitive experiences of people experiencing migration in the first stage of their stay in the new culture are described in the literature as the honeymoon. The honeymoon period experience exemplifies the content of the statement by a Polish migrant who left the country as a young girl:

"[...] In the Netherlands, I enjoyed the fact that people are smiling, open, they call each other by name, they do not create unnecessary problems and distance. For example, nonsense situations - you forget your pin code - become valid for us. In the Netherlands you say with a smile on your face: "I have a day like that too", "I also have all my money gone”. In such situations, people smile - the problem does not exist [...]. [...] And I was surprised by the vitality. At some point, people stop ageing. They are in a good shape. They are aware of a healthy lifestyle. [...] This is also how they raise their children [...].” (Source: Doświadczenia Polaków..., 2017)

However, children from the environment of forced migrants may experience the stay in a new country differently. It is related to the specificity of their migration, which may be linked to the threat of loss of health and/or life in their home coun- 
try (Sellars, 2020). Psychologically, it is often a traumatic situation, the effects of which are observed in the cognitive, affective and behavioral areas of human functioning. Hence, in the case of this group of migrants, usually in the first stages of their stay in the host country, people are more focused on experiencing the effects of trauma than on the excitement of the honeymoon period (Barzykowski et al., 2013, p. 75).

Migration determines many situations in which the migrant's cognitive, affective and behavioral responses have a different meaning and cause different effects than those the individual was used to in one's own country of origin (Kubitsky, 2012, p. 125). If the honeymoon stage meant that everyday experiences were accompanied by positive emotions and a positive perception of a distinctive culture, then the next stage is associated with experiencing a negative culture shock (Boski, 2010, pp. 522-541). It is caused by experiencing the inadequacy of one's own way of functioning in the new environment and the accompanying cognitive disorientation. At some point during staying abroad, a person starts to notice and realize that his or her culture is different from the dominant culture of the host society. The individuals begin to understand that they are different from most people around them. This situation is usually accompanied by the feeling of psychological tension caused by the effort related to psychological adaptation to a new country, its society and culture. One may feel that he or she is losing their relationship with the loved ones, friends, and family members who remain in their country of origin. There is a longing for especially close places. A person may be convinced of rejection by their peers and/or neighbors in a new country. There is uncertainty about the right ways to behave. All this causes surprise, fear, helplessness, and even a kind of disgust and indignation accompanying the realization of the differences between the new and own culture (Barzykowski et al., 2013, p. 75). It is well illustrated by the memories and emotions from the beginning of the stay in a new country, of a migrant from Armenia who came to Poland as a teenager:

"[...] The first months were shocking for me, because I suddenly appeared in a country with different customs, culture and mentality. For example, the fact that the neighbors in one staircase do not know each other very well and do not maintain close contact with each other was contrary to the relationships I had known so far. In Armenia, these relations are very warm, you eat breakfast together, go to the neighbors whenever you want, you don't even close the door, because a neighbor can come at any time. Another shocking example was that girls my age were wearing makeup, dying their hair, smoking cigarettes, drinking beer, and were going out with boys, which is unacceptable, even reprehensible in my country. Another example of being surprised by a different culture was hospitality. For example, when my mother and I were sometimes invited to meet someone, we were most 
often offered coffee or tea, whereas in my country it was a hearty dinner. In Poland, children have a lot of choice in various aspects of life, while in my country there is a lot of pressure from parents, they decide about everything, which has its positive and negative aspects. There are many examples, but I will briefly say that when you begin living in a foreign country, a culturally different one, it is a school of life, you have to be very strong and wise not to make mistakes and not to forget your identity [...]." (Source: Doświadczenia cudzoziemców..., 2017)

The next, third stage of the stay in the new country is acculturation, which can lead to positive and negative results, both in the individual development of the arriving person and the development of the host society. ${ }^{4}$ Anthropologically speaking, acculturation is a process of learning and assimilating the dominant culture of a new country of residence. This process includes children, adolescents and adults (Rodziewicz, 2009, p. 521; Boski, 2010, p. 21). Everyone, regardless of their age, experiences successive stages of the process of adapting to the society and culture of a new country. Therefore, acculturation stress also accompanies children, even the youngest (Borkowska, 2016, p. 103). However, it often happens that in the mind of many adults a child is as if excluded from the effects of acculturation. Adults often believe that children, due to their childlike nature, are unable to understand much or anything at all. Children can, however, be aware of the social and cultural changes that result from migration. They can understand the motives and intentions of adults adequately to their perceptual abilities and, as the experiences of children show, they try to understand and explain the reasons for the departure. The older a child is, the easier it is usually for him or her to rationally understand the reasons for leaving their home country. This state of affairs is clearly exemplified by the statement of the Crimean Tatars, a Polish elementary school student:

4 In this article, the concept of John Berry was used to analyze the processes of foreigners’ entering into a different socio-cultural reality. As, i.a., Małgorzata Budyta-Budzyńska notes that foreigners find themselves in the host society in various ways, therefore various terms are used to describe their degree of 'entering' the host community, and this applies to both everyday life and scientific analyses. There is talk of the separation or marginalization of immigrants, their adaptation, integration or assimilation to the majority environment. Despite the frequent occurrence and intuitive understanding of these terms, there is no consensus as to their exact meaning. The meaning of the quoted terms depends on: the context to which they are applied, or the so-called old, historic, indigenous national and ethnic minorities; or new immigrant nationalities composed of refugees, displaced persons or economic emigrants; from the discipline describing the analyzed cases - these terms are differently defined by anthropology, they are used differently in sociology, and still differently in psychology, economics or theories of politics; from the scientific paradigm, e.g., in the structuralfunctionalist approach (Talcott Parsons), the concept of adaptation is an absolutely key category, in other approaches it does not appear at all, etc. See more: Budyta-Budzyńska (2011). 
“[...] Because there is a war in Crimea. And they forbid going to school in hijab. Before that it was normal. But when the war had started, they began to say that you can't wear headcloths. Either we go to another school or we don't go to school at all. The first reason why we left was that there was a war there, and the second was that we were forbidden to wear hijabs [...].” (Source: Przestrzeń szkoły..., 2019)

Children, just like adults, must understand the new world in which they have to live permanently or temporarily. They need to reconstruct their world and reunderstand themselves in a new country of residence. A big challenge is selfdetermination and building their own world in the case of a multiple changing of the place of residence, which is often faced by children experiencing forced migration. Children with refugee background are often 'on the move':

"I am from Chechnya. I came from Germany. First, I lived in Chechnya. As my fourth birthday was approaching, I came to Poland. I had lived in the center for eight months. Then we returned to Chechnya. And later we came to Poland again. We stayed at the refugee center and in an apartment. I went to ' $\mathrm{X}$ ' and ' $\mathrm{Y}$ ' schools. Then we went to the Netherlands. From the Netherlands, I don't know where - because I was little - I think to Germany. I studied there for three months. And I didn't speak well [German] - so-so [...]. [...] When I came to Poland and met my friends, that's when I started to speak Polish. When I started to speak Polish, that was when I started to have friends. And in Germany, I only had one friend. She was a Tatar. She couldn't speak Russian - only German, because she has been living there since childhood.” (Source: Przestrzeń szkoły..., 2019)

During acculturation, as a result of long-term and most often direct contact with the new culture, there is a gradual transformation of all or selected elements of the new culture (often understood as the dominant culture) within the native culture of people experiencing migration (i.e., within the so-called dominated culture) (Berry, 1998, 2003, 2006). These transformations consist in incorporating into one's culture, on the basis of adaptation, those elements of the culture of the dominant group, which - in recognition - may favor the achievement of a significant goal, for example, remove suffering due to cultural difference or provide an opportunity to get a better job. As a consequence, it causes the abandonment of practicing selected elements of one's own culture and modifying elements of both cultures (restructuring them or giving them new meanings). It is a process in which members of the dominated culture (politically, culturally, socially, economically, etc.) assimilate specific contents of the dominant culture, while losing certain contents of their own culture (Berry, 1998, 2003, 2006).

The acculturation process, the immanent part of which is learning, provides psychological knowledge that results in changes in the value system and set of behaviors, and thus in identity. The source literature distinguishes a number of 
strategies of individual and group adaptation to various cultural systems. For example, John W. Berry writes that the discussed process may end up in integration, assimilation, separation, or marginalization (Berry, 1998, 2003, 2006). The optimal acculturation strategy, from the point of view of mental health and chances for full functioning in a new country, is integration (Berry, 1998, 2003, 2006), which is expressed by maintaining one's own culture while having contact with the new culture. Thanks to integration, people feel that the knowledge and skills they have acquired from the new culture will allow them to eliminate tensions resulting from the differences between themselves, their own cultural group and the new society (Wróblewska-Pawlak, 1995). Acculturation has an active character. It is not about mechanically accepting ready-made content or even patterns of a foreign (dominant) culture, but it is about the specific processing based on the foundation of the native (dominated) culture. As a result, it gives a new cultural quality (Berry, 1998, 2003, 2006). In practice, this means that a well-integrated foreigner has acquired the norms of behavior characteristic of the dominant culture of the host country and knows how to behave in a given social situation for his behavior to be accepted by native speakers of the language and culture of a given country. The course of the acculturation process, the effect of which is integration, is illustrated by the words of the nineteen-year-old Chechen:

\begin{abstract}
"[...] We came in January and I have my birthday in January. I was exactly 7 years old when I came to Poland [...]. The beginnings were not easy [...], e.g., my peers at school called me names. I could not justify my stay in Poland because I did not know Polish so well. Due to the lack of knowledge of the Polish language, I had difficulties with learning in primary school, but with time this problem disappeared, when my peers learned that I am no different from them and that I am the same person as them [...]. [...] I feel safe in Poland and I feel that my home is in Poland. I like the fact that in Poland I have friends who support me and they are with me when I need them. I also like the fact that Poland is developing rapidly in many areas. [...] I feel I am a Chechen. Chechen culture has a lot in common with Polish culture and it teaches about respect for the elderly, parents, peers and younger children. I identify myself with the Chechen culture because being outside my country, I represent the entire nation. Of course, in my daily relations I use the knowledge of Polish culture, which makes my contacts with Poles easier. From Polish culture, among others, I like the cuisine, and Polish soups are the best in the world!” (Source: Doświadczenia cudzoziemców..., 2017)
\end{abstract}

Acculturation - apart from integration, which is considered the most beneficial strategy from the point of view of both the human and the host society - may also take other forms. One of them is assimilation, which consists in rejecting one's own cultural identity and joining a group representing the culture of the new country of 
settlement (Berry, 1998, 2003, 2006). This means that the individual gives up his or her own culture in favor of the dominant culture of the new country of residence (permanent or temporary). It happens that people experiencing migration, whose acculturation process ends with assimilation, consciously deny their own culture, because they are guided by the belief that the new culture is superior to their native culture. A person who decides to adopt this acculturation strategy sometimes sees many benefits of being like the majority of society (an example may be a part of the Polish population living in Chicago). Another acculturation strategy is separation (Berry, 1998, 2003, 2006). It is initiated by a group of foreigners who decide to reject the new - understood as foreign - culture. The motivation here may be: the will to maintain a traditional lifestyle, defending the values belonging to one's own tradition and considered important. At this point, we must also pay attention to the imposed separation. It is created when the separation occurs as a result of the rejection of foreigners by the residents of the country of residence. This strategy is based on the belief that migrant culture is less valuable (Berry, 1998, 2003, 2006). This in turn causes a situation when its users are recognized as people of an inferior species. A telling example of separation is ghettoization, which can be observed in some European countries. People with migration experience reject a new culture and create ghettos, and their own world, the borders of which include their own ethnic or national group. For example, this is how the Arab communities in France, the Mexican ones in the USA, and the Vietnamese ones in Poland function (Boski, 2010, p. 528). The last of the acculturation strategies is marginalization. People who have lost contact with their own culture succumb to it because they consider it inferior, less valuable in relation to the dominant culture of the new country of residence. At the same time, they failed to include themselves into the new society, in the structure of social relations and to become users of the new culture (Berry, 1998, 2003, 2006). Such situation leads to a feeling of alienation and loss of identity, and often to mental disorders and criminogenic behavior. Usually, marginalization is not a conscious choice made by an individual, but a result of failed acculturation.

Distinctness and otherness naturally create the possibility of conflict, which can be valuable and enriching as it may lead to creative conclusions and solutions. It can also be devastating when it leads to regression. Perceiving members of different cultures as interesting, stimulating and valuable fosters interactions based on mutual recognition and respect, and guides them towards cooperation and collaboration. Negative perception based on simplifications and stereotypes develops reluctance and causes conflicts as well as antagonisms (Nikitorowicz, 2005b, p. 105). This applies to both foreigners and the host society. 
Acculturation requires from the individuals to go beyond their ethnocentric point of view, according to which the Strangers and/or the Others are perceived as inferior, because they differ from the generally accepted cultural norm which the person belongs to. It is related to the belief in superiority of the culture of one's own social group and treating one's own rules, norms and values as appropriate. Anything that does not belong to one's own culture is considered inappropriate. The tendency to judge Strangers and Others according to one's own cultural standards is, however, natural, although it hampers intercultural contacts. Intercultural communication becomes effective in the case of adopting an attitude closer to cultural relativism, which makes it possible to interpret the behavior of people with a different cultural affiliation in the context of their own culture. Then, different cultural features are not considered in terms of good-bad and are subject to different evaluation. They are simply treated as different. Thanks to this, it is possible to perceive the Stranger and the Other as interesting and valuable. This approach is accompanied by cognitive curiosity, expressed in the willingness to learn about otherness. However, conscious cognitive effort is an important condition for understanding different ways of thinking and behaving (Gudykunst \& Kim, 2019, p. 497).

The degree of migrant 'entering' the host society is influenced by a number of different factors, their importance and intensity change over time, they directly or indirectly affect an individual or the entire community. They can be divided into three groups - related to the characteristics of the host society (1), to the specificity of the sending society (2), and to the attributes of migrants (3) (Budyta-Budzyńska, 2011). Analogously, in the case of children, many different influences and environments are also significant. The research ${ }^{5}$ and practical experience ${ }^{6}$ of the author of the article on working with migrants (mainly refugees from Chechnya) show that the family environment often does not play a leading role in the process of

5 Those are studies such as: "Formy i metody uczenia się języka polskiego dzieci cudzoziemskich" [Forms and Methods of Learning Polish by Foreign Children] among 15 foreign students at the age of 7-12, method: unstructured interviews. Research implementers: Anna Młynarczuk-Sokołowska, Katarzyna Szostak-Król. Contents of unstructured interviews conducted in 2014 as a part of the study "Międzykulturowa kompetencja komunikacyjna w nauczaniu języka obcego dzieci w wieku 7-12 lat” [Intercultural Communication Competence in Teaching a Foreign Language to Children aged 7-12] among 15 teachers of Polish as a foreign language in primary schools, method: unstructured interview. Research implementers: Anna Młynarczuk-Sokołowska, Katarzyna Szostak-Król.

6 Those are the experiences of working with people with refugee experience at the Residence Center for Foreigners in Białystok (as a methodologist and teacher of Polish as a foreign language) and in Białystok schools (as an intercultural advisor on behalf of the Dialogue Foundation). 
shaping social competences which seem to be necessary to participate in the new culture. Educational institutions (i.e., schools, non-governmental organizations) frequently play more important role than the child's family and parents, and they as well play the role of guides for different cultures and social realities. Important factors are: intensive learning of a new language, getting to know the norms and values of the new society, gaining knowledge about holidays, rituals and customs characteristic of the dominant culture of the new country:

"I study Polish at school during lessons and additional classes. Our class teacher teaches us. We read and do exercises from the book - but we mostly speak in Polish - and we also read. We talk as well - someone asks and you answer. We also draw things and read books, and we learn this way. For example, we drew mosques. We also did the dictation exercise. We also watch movies. For example, we watched a movie about how Poles lived in the past [...].” (Source: Formy i metody uczenia się języka polskiego..., 2014)

"We learn about Polish culture at school. For example, Polish songs, symbols, how different holidays are celebrated... Before Christmas at school we made several postcards for the fair. On Christmas Eve in class, the teacher said that we could prepare some of our dishes and show them to other people. Or tell something about how we celebrate holidays, e.g., Ramadan [...].” (Source: Formy i metody uczenia się języka polskiego..., 2014)

Thanks to school children learn new patterns of behavior, i.e., learn how to behave in a given social situation. Children learn to understand social behaviors which are appropriate to the culture of a new country (Młynarczuk-Sokołowska \& Szostak-Król, 2016).

\section{CHILDHOOD IN THE FACE OF A DIFFERENT CULTURE: EDUCATIONAL CONTEXTS}

Poland is characterized by a relatively low degree of cultural diversity. However, for years there have been children with experience of migration, ${ }^{7}$ whose parents have decided to change their place of residence for economic and professional

7 In recent years, the number of foreign children in Polish schools has increased significantly. Last school year (2018/19) it was 44 thousand children in over 7,000 schools, a year earlier - 30 thousand children in almost 6,000 schools, and in the 2015/16 school year - 14 thousand children in over 3,000 schools. Most foreigners studied in schools in the following voivodships: Masovian, Lower Silesian, and Lesser Poland Voivodship. Retrieved from: https://edukacja.dziennik.pl/aktualnosci/artykuly/608377,dzieci-cudzoziemcy-szkoly-edukacja-narodowosci-nauczyciel.html (access date: 12.11.2020). 
reasons, as well as for fear of losing their safety, health and life and their relatives. ${ }^{8}$ Their situation is varied and determined by many factors which include, among others, specificity of cultural and religious affiliation, experiences in the country of origin, social and economic status. It is largely up to people with migration experience how they find themselves in the new country, what barriers and opportunities they will encounter in a different reality.

From the child perspective, it is often not easy to understand the reasons for migration and to accept the fact of leaving. It happens even despite previous discussions and explanations. The reason for this may be communication difficulties, which frequently result from the parents' inability to adapt the content and form of the message to the age and perceptual abilities of the child, or the surprise with the decision to leave. It is also not easy to part with peers, grandparents or favorite and often visited places that are an integral part of a child's microcosm (Nikitorowicz, 2005b). For a child - like for an adult in this situation - it is difficult to imagine a future of the so-called emigration, what will this new reality look like: who will be their friend, what will be the nearby backyard or school.

The analysis of the source literature ${ }^{9}$ content and the experience of the author of the text related to working in a culturally diverse environment in Poland show that the process of acculturation of children whose parents decided to migrate for economic reasons (e.g., Ukrainian children) ${ }^{10}$ is often different from the one of ref-

8 According to the Geneva Convention, a foreigner is granted the refugee status if, due to justified fear of repression in the country of origin, race, religion, nationality, political belief or belonging to a specific social group, he or she cannot or does not want to benefit from the protection of this country. For more, see Convention Relating to the Status of Refugees, Geneva, 28 July 1951, Art. 1; Act on granting protection to foreigners within the territory of the Republic of Poland of June 13, 2003, item 3. In Poland, relatively few foreigners receive international protection. According to the annual Information of the Head of the Office for Foreigners, the voice of June 13, 2003 on granting protection to foreigners within the territory of the Republic of Poland with regard to the fulfillment of the obligations of the Republic of Poland, with the Geneva Convention relating to the Status of Refugees and the New York Protocol regarding the Refugee Status for years, the most numerous group of foreigners who apply for international protection have been citizens of Russia (of Chechen nationality). In 2019, 272 people were granted international protection (refugee status, subsidiary protection). They were citizens of Russia (81), Turkey (49), Tajikistan (29), Ukraine (21), and Iran (19). In addition, 213 people received the so-called national protection (tolerated stay or for humane reasons). More: Inter-protection in 2019, Reports. Retrieved from: https://udsc.gov.pl/ (access date: 10.11.2020).

9 See i.a.: Zapolska, \& Pająk-Bener (2019); Jawor, Markowska-Manista, \& Pietrusińska (2020); Młynarczuk-Sokołowska (2020); Górska, \& Korczak (2014); Kubin, \& Świerszcz (cooperation) (2014).

10 Among Ukrainian children who live in Poland, there are both individuals whose parents have decided to change their place of residence for economic reasons and for fear of losing the safety of the whole family (refugees). 
ugee children - especially with a significantly different cultural background (e.g., from Chechnya). Important elements are the similarity of cultures and religions (as in the case of Ukrainian culture), disparity of cultures and religions (as in the case of Chechen culture), the direct cause of leaving one's own country and related fear of loss of health and/or life. In the case of a huge cultural difference, migrants' behavior is sometimes perceived as, at least, strange, often even inappropriate and aggressive, which is the basis for misinterpretation. It is usually the result of an insufficient knowledge of the culture of people coming to the host society.

An important perspective of looking at the culture that 'programs"11 human behavior and aspirations is the concept of psychological dimensions of culture by the already quoted Geert Hofstede. His concept is the result of extensive empirical research, ${ }^{12}$ which allowed the author to grasp and comprehend the differences between cultures in the areas of interpretation and perception of the world, as well as understanding the behavior of people (including children) coming from different cultures, e.g., starting to function in a new cultural environment. At the center of his thinking about culture and cultures, Hofstede put values, which allowed to distinguish five dimensions of national cultures that determine human behavior. This concept makes it possible to describe the behavior of members of a given cultural and social group and may constitute a theoretical ground for intergroup comparisons. Hofstede distinguished the following levels of national cultures on which cultural differences are embedded:

- power distance, hierarchy (the degree of hierarchization of countries, the multiplicity of levels and the division of power). Cultures are characterized by an unequal distribution of power in a society. For people from cultures defined by a high power distance, obedience to all forms of sovereignty is obvious. Therefore, people who occupy a higher position in the social hierarchy are respected depending on the relationship and social situation, they have the right to special privileges and decide on the way people in lower positions function. There is a social consent to authoritarian behavior on the part of people occupying a higher position in the social hierarchy, and thus to make top-down decisions that, in their opinion, are beneficial to those in a subor-

11 Hofstede uses the conceptualization 'software of the mind'. See more: Hofstede, Hofstede, \& Minkov (2010).

12 The participants of G. Hofstede's project were 116,000 employees of IBM company. The research was conducted in 53 countries (16 more post-communist countries were added later) (Hofstede, Hofstede, \& Minkov, 2010). 
dinate relationship. In return, the subordinate individuals are cared for and receive help for which they should express their gratitude; ${ }^{13}$

- individualism-collectivism (type of social structure and interpersonal ties, the role of the group and the scope of expectations towards it). Members of individualistic cultures place the need to express and maintain their opinion at the center and feel the need to pursue their own goals and needs. This is more important than building and cultivating social relationships (including group ones). In individualistic cultures, regulations apply to everyone regardless of their position in the social hierarchy. The individual has the right to personal freedom and self-realization. Different ways of thinking and behaving are accepted and do not cause rejection or pressure that requires submission to the majority (conformism). In collectivist societies, people feel strongly identified with families and/or other social groups who offer protection and security in exchange for loyalty; ${ }^{14}$

- masculinity-femininity (gender in society, division of roles and tasks). The male dimension of culture is expressed through striving to achieve material success and high social position. Important pillars of highly masculine cultures are the pursuit for progress, goals, work, and the need to compete. Therefore, authorities should show a firm and assertive attitude. It is crucial to be exemplary on various levels. The structure of these cultures emphasizes the superior position of men. In male societies, women should express tenderness and care for interpersonal relationships. There are also clearly marked divisions into roles, both in public and private life. The female pole of this dimension is the focus on quality of life, women should 'be' rather than 'have'. Female societies consider it a fundamental value to care for and protect others. Friendly interpersonal relationships are paramount and that is why women and men can show tenderness and care for them. The living and spiritual matters of the family are the subject of care for both parents; ${ }^{15}$

13 Poland is characterized by a high power distance, although not as high as South America, West Africa and Arab countries. Countries with a low power distance include: Australia, Austria, the Netherlands, the United States, and New Zealand.

14 In this dimension, Poland is relatively low. Polish society, however, is moving towards individualism. The highest results in this respect were achieved by the United States, Great Britain, Australia, Canada, and the Netherlands. The lowest results were achieved by the countries of South America, Indonesia and Pakistan.

15 In this respect, Poland is on an average level. Among others, Sweden, Norway and the Netherlands have low values of the male index. Countries with high male index values include, for example, Japan, Austria, and Venezuela. 
- avoiding uncertainty (the degree of avoiding unclear situations, creating norms, social contracts and the scope of their respect). Cultures with a high level of uncertainty avoidance are characterized by the fact that their members feel threatened in new, unknown or uncertain situations. Uncertainty and ambiguity, which are part of many life situations, are source of anxiety and stress. People belonging to this type of culture strive to obtain an unambiguous interpretation of situation in which they find themselves. Individuals who perceive and interpret the world differently are rejected. In cultures with a high degree of avoidance of uncertainty, unquestionable and restrictive norms of behavior are formulated, which is manifested by the existence of many regulations, attaching importance to punctuality, precise formulation of one's thoughts, and also to hard work. This is why experts are particularly trusted in this type of culture. Societies with a low degree of uncertainty avoidance do not have an extensive system of rules, and if existing regulations are not respected, they need to be changed. There is an acceptance of civil protests in these societies. The access of citizens to the state institutions is characteristic for such cultures, as well as the positive attitude of state officials to politics. These societies are tolerant and friendly towards young people. Faith in common sense and the power of generalizations dominate. It is believed that the rules and rights of one social group should not be imposed on another and that no one should be victimized because of their beliefs; ${ }^{16}$

- distant-close time orientation (making decisions focused on tradition, the past or the present and the future). Societies with a short-term orientation are characterized by the respect for tradition, as well as social and statutory obligations, regardless of the incurred costs. At this pole of dimension, there is a social pressure to match the other person, even if it involves money overspending. People expect quick results, they strive for truth and to 'save their face'. Societies with a long-term orientation adapt the incorporation of traditions into contemporary situations. Although, they have limited respect for social and statutory obligations. People are patient with the expectation of slow results, and it is natural for them to strive to respect the requirements of integrity. They submit to goals, are proactive and use resources sparingly. ${ }^{17}$

16 Poland is a country with a moderate degree of uncertainty avoidance. The highest scores in this area were obtained by Greece, Portugal, South American countries, and Japan. The Scandinavian countries, Great Britain and Ireland had low results.

17 See more: Hofstede, Hofstede, \& Minkov (2010). 
Geert Hofstede's concept makes it possible to study and understand significant differences in the social and cultural functioning of people in a situation where cultures meet. It allows us to understand that the cultural difference is one of many dimensions of a child's subjectivity and it determines the cultural nature of his or her identity and personality. Hofstede's concept can be useful for researching and explaining those situations in which there is a significant distance between the culture of people experiencing migration and the culture of the host society. The analyses of situation where cultures meet show that there is often a conflict resulting from different values, beliefs, needs, etc. The new culture may arouse many emotions and questions among people experiencing migration. From the perspective of a host society, the behaviors of children and their parents may be perceived as strange and/or inadequate to the situation. However - as Hofstede presents - this is the effect of too large distances between cultures and communities, and the behavior of their representatives (even if extreme) seems normal, in a situation that may appear at least strange.

Children who grew up in low power distance cultures prior to relocation are likely to communicate with adults in a partner-like way. They will not create a distance due to the age and social position of an adult. On the other hand, children from cultures characterized by a high power distance, in their social relations with adults may show considerable respect because they are used to the fact that adults require submission from them. They will probably present behavior informing about respecting authority and try to follow all the instructions, even when they are not able to understand them and if they do not feel they are justified. Children will rarely try to answer questions that are not directed at them. Likewise, they will not ask their own questions or ask for additional explanations of issues that are unclear or require additional information for them. Their statements will be more focused on giving the correct answer than on presenting their own point of view. Children brought up in cultures characterized by a high power distance in various social situations (e.g., during educational classes) will probably wait for the initiative of an adult.

In individualistic cultures, children are taught to think in the category of 'Me'. Therefore, in relations with their peers and the elderly, they may ask many questions, challenge the validity of commands and give a lot of information centered around themselves, which may be negatively perceived by the others. Children from collectivist cultures are taught to reason in terms of 'Us'. The rule respected by them, in a more or less conscious way, will be trying to avoid conflicts and maintaining harmony, which is connected, inter alia, with subordination to authorities and the elderly. Young people are taught that difficult situations which 
are not resolved constructively, result in a sense of shame and losing the face for both the individual and the social group to which they belong.

Children whose national culture is highly masculine are usually used to traditional perception of female and male roles and they identify themselves with this division. People brought up in these types of cultures will probably perceive a woman and a mother as a sensitive person who cares primarily about the family and interpersonal relationships. This way of perceiving the female role may result, inter alia, in the fact that for them education is not that important. Thus, girls may have a stronger sense of responsibility for caring for their siblings, for example, than for their own education. They will recognize a man and a father of the children as a man fighting for his own, somebody who cares about the social and living matters of the family and somebody who should ensure a peaceful and secure future for them all. In male societies, a boy cannot show weakness, e.g., by crying. They are allowed to resolve conflicts through confrontation and force. Girls, on the other hand, should not get into fights. In their case, crying is an acceptable form of emotional expression. Strong individuals are well thought of by the others, therefore adults (including teachers) are valued for their competences and education, and children are valued for good academic results. People deriving from female cultures are usually used to the fact that social, living and spiritual matters are the subject of care for both parents. Crying is considered a normal reaction and is neither an insult to the boy nor to the girl. The content of books for children indicates gender equality. At schools, boys and girls attend the same subjects. Teachers are valued for their friendly attitude towards the student. Conflict situations are resolved through compromise and negotiation. It goes beyond solutions based on confrontation of power and aggression. In such societies, weaker students are treated with affection in school relationships, and average students are the norm.

Children deriving from societies with a high degree of uncertainty avoidance can find it more difficult to engage themselves in new situations and take on new challenges. Relationships with peers who think and behave variously may seem much more difficult than with peers who are interpersonally and culturally similar. Children who have been raised in cultures with a high degree of uncertainty avoidance are likely to work conscientiously, to formulate their thoughts precisely as well as to be punctual.

Children from cultures with a close time orientation are likely to be focused on the present and the past. Attachment to what is here and now, as well as traditional values and patterns of behavior, may be more important to them than caring for the future, which is associated with the need to obtain a solid education and, 
consequently, diligent work. People with a long-term time orientation will probably try to be good learners and see this as a factor for future success.

\section{CONCLUSIONS: TOWARDS INTERCULTURAL INTEGRATION}

The meetings of cultures are characterized by the fact that they are attended by people who think about the same social issues and situations in at least two ways. Assuming that differences may have a positive potential, a person has a chance to 'build' them into his or her biography and thus expand or even reconstruct his or her personal social and cultural identity. It depends to a large extent on a person, whether and how this potential will be used to reconstruct one's own identity. The way it is 'built' into a person's biography determines whether the experience of meeting cultures will be noticed as assimilation, separation, marginalization, or integration (Kożyczkowska \& Młynarczuk-Sokołowska, 2018).

Due to the intensification of migratory movements, modern societies are becoming more and more culturally diverse. In recent decades, thanks to a series of social processes, there has been an intensified transformation of Poland's 'cultural landscape'. The territory of Poland is inhabited by people with experience of migration, whose decision to change their place of residence was determined by a number of factors: from economic, through professional, to those related to the lack of security in their own country. The culture of foreigners living in Poland differs to a greater or smaller extent from Polish culture.

The process of assimilating the dominant culture of the new country of residence (acculturation) is complex, multi-faceted and leads to changes in one's own cultural behavior and identity. Finding oneself in a distinct reality requires getting to know the new cultural environment well. The more the culture which a child comes from differs from the Polish one in terms of the system of values, interpersonal relations or the system of functioning, the more difficult it will be to find oneself in a new cultural environment.

Many behaviors of children with a migration experience (like adults) may be recognized by the host society as strange, incomprehensible and/or aggressive. This can arouse negative emotions and lead to conflicts. Fear of the unfamiliar and unknown is natural and can spontaneously trigger many defensive reactions. That is why, one's involvement in education which will provide knowledge and create conditions where the cultural difference will be practiced is so important. The priority is therefore education that will involve parents, children (students) and other learning entities. Its aim should be - apart from providing knowledge - also 
shaping attitudes and arousing the awareness of the multiculturalism of the host society. Formal (school) and informal (no school) education are very important elements of the acculturation process and should necessarily involve adults and children with migration experience as well as adults and children from the host society. Intercultural integration cannot be understood as a one-dimensional process that will require the unquestionable adaptation of immigrants to the society and culture of the country of residence. Intercultural integration is a challenge and a cultural task for both sides, and the commitment is a manifestation of awareness and it involves taking responsibility for the world we inhabit together.

It is worth emphasizing that all experiences of migration have a biographical influence and result in the reconstruction of human identity. This aspect of the meeting of cultures is particularly important in the case of children and their childhood. The school is often unable to cope with children's experiences and their pre-migration national-ethnic identification, migration (physical displacement) and the consequences of settling into the host country (Kożyczkowska \& Młynarczuk-Sokołowska, 2018). It is about the child's first identity, shaped by his or her cultural heritage of the family home, which determines who the child is (Nikitorowicz, 2005b).

The challenge for schools/educational leaders is to develop a whole school approach to inclusion and integration of these students as a priority because the contact that students will have initially with the dominant, host country begins when they start to be learners at school (Sellars, 2020). If the education does not find a place in its spaces for the values a child brings with him or her, it is like giving the child a signal that his or her culture, and thus also the child, is something unacceptable, because - perhaps - worse. The child brings his or her social and cultural identity into social interactions, so the school should pay special attention to this dimension of the child's identity.

\section{References}

Barzykowski, K., Grzymała-Moszczyńska, H., Dzida, D., Grzymała-Moszczyńska, J., \& Kosno, M. (2013). One sq wśród nas. Wybrane zagadnienia diagnozy psychologicznej dzieci i młodzieży w kontekście wielokulturowości oraz wielojęzyczności. Warszawa: Ośrodek Rozwoju Edukacji.

Bednarski, J. (1987). Enkulturacja. In: Z. Staszczak (Ed.), Słownik etnologiczny. Terminy ogólne (pp. 75-77). Warszawa-Poznań: Państwowe Wydawnictwo Naukowe.

Berry, J.W. (1998). Acculturation and Health: Theory and Research. In: S.S. Kazarian, \& D.R. Evans (Eds.), Cultural Clinical Psychology: Theory Research and Practice (pp. 39-57). New York: Oxford University Press.

Berry, J.W. (2003). Conceptual Approaches to Acculturation. In: K.M. Chun, P. Balls Organista, \& G. Marin (Eds.), Acculturation: Advances in Theory, Measurement, and Applied Research (pp. 17-37). Washington: APA. 
Berry, J.W. (2006). Contexts of Acculturation. In: D.L. Sam, \& J.W. Berry (Eds.), The Cambridge Handbook of Acculturation Psychology (pp. 27-42). Cambrige: Cambrige University Press.

Borkowska, A. (2016). Psychologiczne aspekty migracji w rozwoju dziecka. In: E. Śmiechowska-Petrovskij (Ed.), Dzieci z trudnościami adaptacyjnymi w młodszym wieku. Aspekty rozwojowe i edukacyjne w kontekście specyfiki różnic kulturowych (pp. 101-123). Warszawa: Wydawnictwo Naukowe UKSW.

Boski, P. (2010). Kulturowe ramy zachowań społecznych. Podręcznik psychologii międzykulturowej. Warszawa: Wydawnictwo Naukowe PWN.

Budyta-Budzyńska, M. (2011). Adaptacja, integracja, asymilacja - próba ujęcia teoretycznego. In: M. Budyta-Budzyńska (Ed.), Integracja czy asymilacja? Polscy imigranci na Islandii (pp. 44-65). Warszawa: Wydawnictwo Naukowe Scholar.

Dyczewski, L. (1996). Naród podmiotem kultury. In: L. Dyczewski (Ed.), Tożsamość polska i otwartość na inne społeczeństwa (pp. 11-38). Lublin: Redakcja Wydawnictw KUL.

Górska, K., \& Korczak, L. (2014). Integracja w szkole dzieci z rodzin uchodźców. Edukacja Ustawiczna Dorosłych, 4.

Gudykunst, W.B., \& Kim, Y.Y. (2019). Komunikowanie się z Obcymi: spojrzenie na komunikację międzykulturową. Trans. J. Rączaszek. In: J. Stewart (Ed.), Mosty zamiast murów. O komunikowaniu się między ludźmi (4 ${ }^{\text {th }}$ Ed.) (pp. 496-512). Warszawa: Wydawnictwo Naukowe PWN.

Hall, E.T. (1976). Beyond Culture. Garden City, NY: Anchor Books.

Hofstede, G., Hofstede, G.J., \& Minkov, M. (2010). Cultures and Organizations: Software of the Mind: Intercultural Cooperation and Its Importance for Survival. New York: McGrawHill.

Jawor, A., Markowska-Manista, U., \& Pietrusińska, M.J. (2020). Konkultura. Wymiary uczestnictwa w kulturze młodych imigrantów z Ukrainy w Polsce. Warszawa: Wydawnictwo Naukowe Scholar.

Jurgiel-Aleksander, A. (2013). Doświadczenie edukacyjne w perspektywie andragogicznej. Studium biograficzno-fenomenograficzne. Gdańsk: Wydawnictwo Uniwersytetu Gdańskiego.

Kożyczkowska, A., \& Młynarczuk-Sokołowska, A. (2018). Kulturowe konteksty dzieciństwa. Szkice antropologiczno-pedagogiczne. Gdańsk: Wydawnictwo Naukowe Katedra.

Kubin, K., \& Świerszcz, J. (cooperation) (2014). „Równe traktowanie po omacku”. Raport z badania dotyczqcego zjawiska wykluczenia dzieci z doświadczeniem migracji w szkołach w Polsce oraz podejmowanych działań zmierzających do ich integracji. Warszawa: Fundacja na rzecz Różnorodności Społecznej.

Kubitsky, J. (2012). Psychologia migracji. Warszawa: Wydawnictwo Difin.

Matsumato, D., \& Juang, L. (2007). Psychologia międzykulturowa. Trans. A. Nowak. Gdańsk: Gdańskie Wydawnictwo Psychologiczne.

Młynarczuk-Sokołowska, A. (2020). Na uchodźczej ścieżce. Doświadczenie przymusowej migracji w procesie edukacji formalnej. Forum Pedagogiczne, 10(2).

Młynarczuk-Sokołowska, A., \& Szostak-Król, K. (2016). Zrozumieć Innego. Międzykulturowa kompetencja komunikacyjna w procesie uczenia się języka polskiego jako obcego ( $\left.2^{\text {nd }} \mathrm{Ed}.\right)$. Białystok: Fundacja Dialog.

Nikitorowicz, J. (2005a). Kreowanie tożsamości dziecka. Wyzwania edukacji międzykulturowej. Gdańsk: Gdańskie Wydawnictwo Psychologiczne. 
Nikitorowicz, J. (2005b). Mikroświat dziecka w ustawicznym procesie kreowania tożsamości. Problemy Wczesnej Edukacji, 2(2), pp. 23-30.

Nikitorowicz, J. (2009). Edukacja regionalna i międzykulturowa. Warszawa: Wydawnictwa Naukowe i Profesjonalne.

Rickert, H. (2003). Człowiek i kultura. In: G. Godlewski, \& A. Mencwel (Eds.), Antropologia kultury. Zagadnienia i wybór tekstów (pp. 364-369). Warszawa: Wydawnictwa Uniwersytetu Warszawskiego.

Rodziewicz, A. (2009). Akulturacja. In: W. Antosik, B. Jaskłowska-Ferreras, M. Kardasz, \& K. Kubalska-Sulkiewicz (Eds.), Słownik wiedzy o kulturze (p. 521). Warszawa: Arkady.

Sellars, M. (2020). Educating Students with Refugee and Asylum Seeker Experiences: A Commitment to Humanity. Opladen-Berlin-Toronto: Verlag Barbara Budich.

Wróblewska-Pawlak, K. (1995). Dwujęzyczność a dwukulturowość. In: A. Kapciak, L. Korporowicz, \& A. Tyszka (Eds.), Komunikacja międzykulturowa - zbliżenia i impresje (pp. 69-78). Warszawa: Instytut Kultury Uniwersytetu Warszawskiego.

Zapolska, A. \& Pająk-Bener, D. (2019). Analiza przeprowadzonego ankietowania rodziców uczniów z Ukrainy oraz kadry pedagogicznej szkół i placówek edukacyjnych w Krakowie. Kraków: Fundacja Zusticz.

\section{Legal acts}

Konwencja dotycząca statusu uchodźców sporządzona w Genewie dnia 28 lipca 1951 r. (Dz. U. z 1991 r. Nr 119, poz. 515 i 517).

Ustawa o udzielaniu cudzoziemcom ochrony na terytorium Rzeczpospolitej Polskiej z dnia 13 czerwca 2003 r. (Dz.U. z 2003 r. Nr 128, poz. 1176 z późn. zm.).

\section{Empirical material}

Formy i metody uczenia się języka polskiego dzieci cudzoziemskich [Forms and Methods of Learning Polish by Foreign Children] (2014) by Anna Młynarczuk-Sokołowska \& Katarzyna Szostak-Król.

Międzykulturowa kompetencja komunikacyjna w nauczaniu języka obcego dzieci w wieku 7-12 lat [Intercultural Communication Competence in Teaching a Foreign Language to Children Aged 7-12] (2014) by Anna Młynarczuk-Sokołowska \& Katarzyna Szostak-Król.

Doświadczenia cudzoziemców dotyczące akulturacji w Polsce [Experiences of Foreigners Regarding the Acculturation Process in Poland] (2017) by Anna Młynarczuk-Sokołowska.

Doświadczenia Polaków związane z akulturacją w wybranych krajach europejskich oraz migracją powrotną [Poles' Experiences Related to Acculturation in Selected European Countries and Return Migration] (2017) by Anna Młynarczuk-Sokołowska.

Przestrzeń szkoły w percepcji uczniów z doświadczeniem migracji uchodźczej [Space of School in the Perception of Students with Refugee Background] (2019) by Anna Młynarczuk-Sokołowska. 